\title{
On the morphology of an endemic copepod Acanthocyclops tomilovi Mazepova, 1978 (Copepoda: Cyclopoida: Cyclopidae) from Lake Baikal
}

\author{
N.G. Sheveleva1, O.G. Pen'kova², E.A. Misharina² \\ ${ }^{1}$ Limnological Institute of the Siberian Branch Russian Academy of Sciences, Ulan-Batorskaya Str. \\ 3,Irkutsk664033 Russia.E-mail: shevn@lin.irk.ru \\ ${ }^{2}$ Irkutsk State University, K. Marksa Str. 1, Irkutsk664003 Russia.E-mail:olg-penkova@yandex.ru, \\ solevgeniya@yandex.ru
}

ABSTRACT. We studied the morphology of the Baikalian endemic copepod Acanthocyclops profundus tomilovi Mazepova, 1978 (Copepoda: Cyclopoida: Cyclopidae) using scanning electron microscopy. Appendages of the dorsal surface of the basipodite of antenna 2 and the coxopodite of the female swimming leg 4 are studied in detail for the first time. Morphometric indices of this subspecies are represented in comparison with those of A. profundus profundus. Based on our analysis, we can conclude that Acanthocyclops tomilovi Mazepova, 1978 must be regarded as a full species.

How to cite this article: Sheveleva N.G., Pen'kova O.G., Misharina E.A. 2018. On the morphology of an endemic copepod Acanthocyclops tomilovi Mazepova, 1978 (Copepoda: Cyclopoida: Cyclopidae) from Lake Baikal // Invert. Zool. Vol.15. No.3. P.299-307. doi: 10.15298/invertzool.15.3.08

KEY WORDS: Crustacea, Copepoda, Cyclopoida, morphology, Lake Baikal.

\section{О морфологии эндемичной копеподы Acanthocyclops tomilovi Mazepova, 1978 (Copepoda: Cyclopoida: Cyclopidae) из озера Байкал}

\author{
Н.Г. Шевелева ${ }^{1}$, О.Г. Пенькова², Е.А. Мишарина²
}

\author{
${ }^{1}$ Лимнологический институт Сибирского Отделения РАН, ул. Улан-Баторская, 3, Иркутск, \\ 664033, Россия.E-mail:shevn@lin.irk.ru \\ ${ }^{2}$ Иркутский государственный университет, ул. К. Маркса, 1, Иркутск, 664003, Россия. Е- \\ mail: olg-penkova@yandex.ru,solevgeniya@yandex.ru
}

РЕЗЮМЕ: Морфология байкальской эндемичной копеподы Acanthocyclops profundus tomilovi Mazepova, 1978 (Copepoda: Cyclopoida: Cyclopidae) изучена при помощи сканирующего электронного микроскопа. Впервые приведены сведения о придатках задней стороны базиподита антенны (А2), коксоподита 4 плавательных ног самки. Приведена таблица морфометрических показателей данного подвида в сравнении с $A$. profundus profundus. На основании сравнительного анализа двух таксонов можно сделать вывод о статусе самостоятельного вида Acanthocyclops tomilovi Mazepova, 1978.

Как цитировать эту статью: Sheveleva N.G., Pen'kova O.G., Misharina E.A. 2018. On the morphology of an endemic copepod Acanthocyclops tomilovi Mazepova, 1978 
(Copepoda: Cyclopoida: Cyclopidae) from Lake Baikal // Invert. Zool. Vol.15. No.3. P.299-307. doi: 10.15298/invertzool.15.3.08

КЛЮЧЕВЫЕ СЛОВА: Crustacea, Copepoda, Cyclopoida, морфология, оз. Байкал.

\section{Introduction}

Although molecular-genetic approaches are currently widely accepted in taxonomy, the role of morphological systematics remains very important. Moreover, detailed re-investigations of many crustacean taxa is an important direction of recent taxonomic studies. Such revisions are necessary for taxa described earlier (i.e. in the first two thirds of the 20th century), as the latter appear to be insufficient and do not meet the requirements of modern taxonomic descriptions.

Investigations of G.F. Mazepova on the morphology of the endemic Baikalian cyclopoids (Copepoda: Cyclopoida) were carried out in the middle of the 20th century (Mazepova, 1950) and her summarizing monograph was published in 1978 (Mazepova, 1978). The author's descriptions were too brief and as a result, some taxa described by her need to be reinvestigated based on the current standards of morphological descriptions used in copepod taxonomy.

The present work aims at a scanning electron microscope (SEM) study of a endemic copepod Acanthocyclops profundus tomilovi Mazepova, 1978, inhabiting the sublittoral zone of Lake Baikal, and a discussion of its taxonomic status.

\section{Material and Methods}

We analyzed samples collected in September 2016 from Bolshie Koty Bay of Lake Baikal (N51 $\left.{ }^{\circ} 55^{\prime} 13^{\prime \prime} \mathrm{E} 105^{\circ} 02^{\prime} 18^{\prime \prime}\right)$ preserved in $96 \%$ ethanol. Mature females and males were selected for morphological analysis under a stereomicroscope. Species identification was based on keys of Mazepova (1978). Specimens were measured according to Kozminski (1936) and the setae on the caudal rami are designated according to Dussart and Defaye (Td - dorsal seta; Te — outer apical seta; $\mathrm{Ti}$ - inner apical seta; Tme - outer median seta; Tmi - inner median seta) (2001). An optical microscope Olympus CX 41 (Olympus, Japan) was used for the morphometric study. The length of the specimens was measured from the tip of the rostrum to the end of the caudal ramus. We also measured the length and the width of the apical endopodite segment P4End3 (P4 swimming leg) and length of the outer and inner apical spine (P4End3). Fixed specimens were kept in hexamethyldisilazane for 24 hours, then air-dried, sputtered with gold and studied under a scanning electron microscope Philips SEM 525Ì (Philips, The Netherlands).

\section{Results}

Order Cyclopoida Burmeister, 1834 Family Cyclopidae Dana, 1846

Genus Acanthocyclops Kiefer, 1927

Acanthocyclops tomilovi Mazepova, 1978

Material. Samples were collected by divers from the littoral and sublittoral zones of the lake at the depths of 5-30 $\mathrm{m}$ and by a dredge at the depths of 30-50 $\mathrm{m}$ from different substrates. In early September, the population included males as well as females with egg sacs.

Diagnosis. Female body length about 1200 $\mu \mathrm{m}$. Body shape stout, egg-shaped. Cephalothorax short, equal in length and width, the widest body portion at the level of cephalothorax posterior end (Fig. 1A-F). All thoracic segments of same structure, clearly separated from each other. Genital segment relatively short (about $250 \mu \mathrm{m}$ ), broader in its anterior portion. Posterior margin of abdominal segments 1-3 serrated dorsally. Anal plate poorly defined (Fig. 1E). Caudal rami short, located subparallel, smooth, bearing few hairs on the internal sides in some specimens. Furcal index 


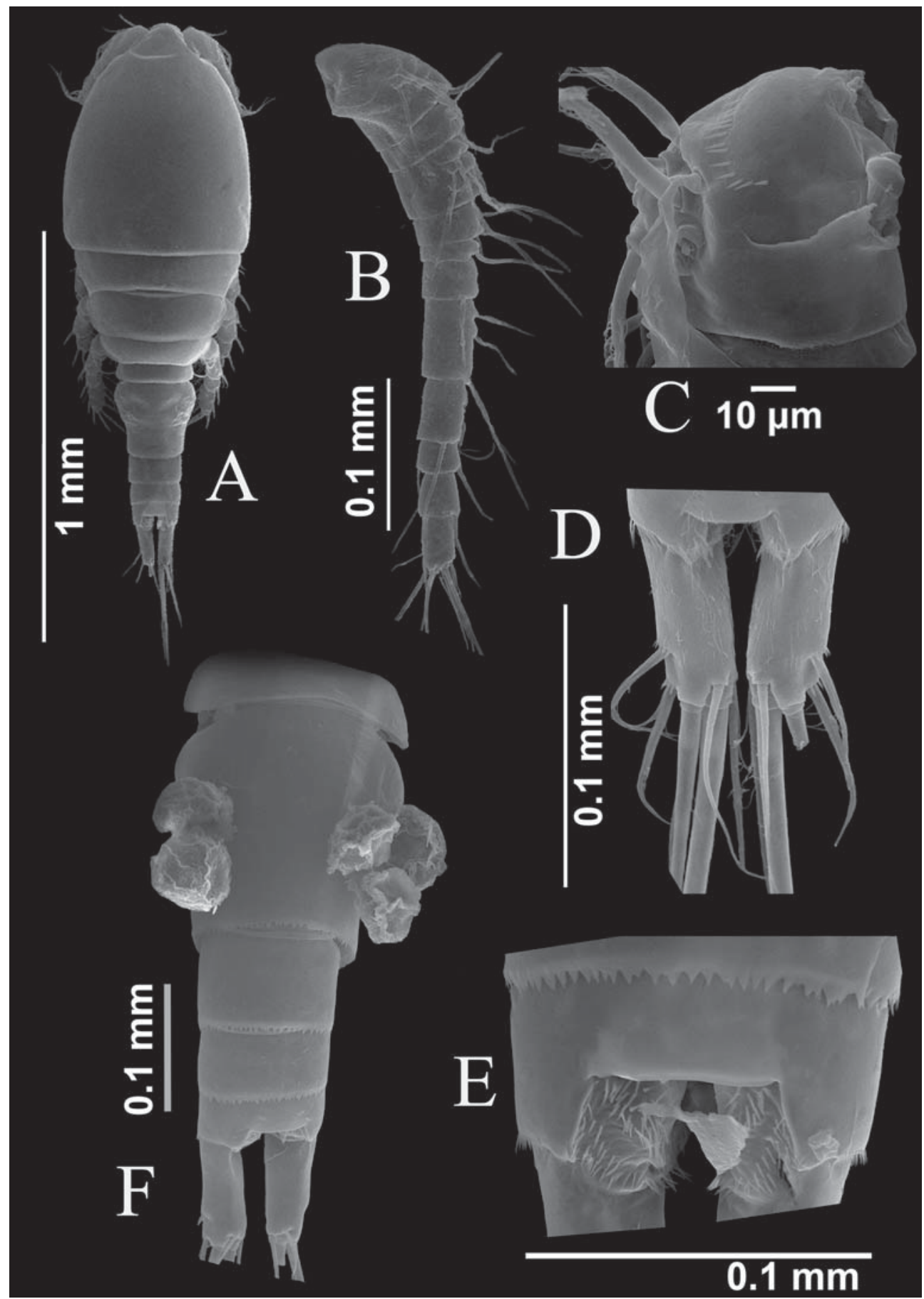

Fig. 1. Acanthocyclops tomilivi, female. A - dorsal view; B - antennule; C - fist segment of antennule; $\mathrm{D}$ - furcal rami; E - anal somite; F - urosoma, ventral view.

Pис. 1. Acanthocyclops tomilivi, самка. А - общий вид, дорсально; В - антеннула; C - базальный членик антеннулы; D - каудальные ветви; E — анальная пластинка; F — абдомен с генитальным сегментом. 
Table 1. Number of spines and setae on swimming legs 1-4 (P1-P4) in Acantocyclops tomilovi. Таблица 1. Количество шипов и щетинок на плавательных ногах 1-4 (P1-P4) Acantocyclops tomilovi.

\begin{tabular}{ccccc}
\hline Leg & Coxa & Basis & Endopodite & Exopodite \\
\hline P1 & $0-1$ & $1-1$ & $0-1 ; 0-2 ; 1-5$ & $1-1 ; 1-1 ; 2-4$ \\
P2 & $0-1$ & $0-1$ & $0-1 ; 0-2 ; 1-5$ & $1-1 ; 1-1 ; 3-4$ \\
P3 & $0-1$ & $0-1$ & $0-1 ; 0-2 ; 1-5$ & $1-1 ; 1-1 ; 3-4$ \\
P4 & $0-1$ & $0-1$ & $0-1 ; 0-2 ; 2-3$ & $1-1 ; 1-1 ; 3-4$ \\
\hline
\end{tabular}

Note: Number of spines first, followed by the number of setules in each formula.

varies from 2 to 2.6. Lateral seta relatively long, $1 / 3$ of the caudal rami length, with spinules near base. Dorsal seta (Td) 1.2 times longer than Te; Ti longer that Te; Tmi the longest: 1.8 times longer than Tme (Table 1).

Antennule 11-segmented, short, its lenghth $1 / 3$ of cephalothorax length. A series of fine spinules arranged in a semi-circular row at the base of the first segment (Fig. 1C). Antennula armature: I(8)-II(3)-III(7)-IV(4)-V(2)-VI(3)VII(3)-VIII(2)-IX(2)-X(2)-XI(7).

Antennal basipodite with fine spinules (Fig. 2A, B) and three setae, one of which very long. Endopodite 3-segmented, segments 1, 2 and 3 of antennal endopodite with spinules transversely located at outer margin. Two transverse parallel rows of spinules on segments 1 and 2. Segment 3 with spinules arranged in a single, disrupted row (Fig. 2A, B).

Mandibule with 12-14 long, acute teeth and a single plumose seta. Maxillula and maxilla as in Fig. 2D, E.

Maxilliped with syncoxa, basipodite and bilobed endopodite. Few fine spinules on frontal surface of basipodite and on first endopodite segment (Fig. 2F).

Swimming legs (P1-P4) segmentation 33/ $33 / 33 / 33$ (first number in this pair designates exopodite). Formula of spines and spinules is given in Table 2. Couplers P1-P2 bare. Caudal side of coupler P3 with a row of long fine setules. Caudal side of coupler $\mathrm{P} 4$ with two rows of long fine setules (Fig. 3A). Inner margins of basipodite of P1-P4 with dense, long setules. Caudal surface of coxopodite of P1 and P2 without an ornamentation, caudal surface of coxopodite P3 with a single continuous row of spinules - A (Fig. 3D). External side of coxa of P3 and P4 with continuous row of solitary spinules. Armament of coxa of P4: A, C+D (continuous row of spinules). Caudal side of coxopodite of P3 and P4 with a set of hairs (Fig. 3C, D). Distal segment P4 End3 1.7 times longer than the width, apical spines relatively thin, inner spine slightly longer than outer one (Table 2). Distal segment of P5 rectangular, 1.5 times longer than the width, armed with small spine less the segment width, and a long seta 15 times longer than the spine. Egg sacs large with 18-20 eggs in each sac.

\section{Discussion}

The fate of the type material of $A$. profundus tomilovi is unknown. Both "subspecies" sensu Mazepova (1978), A. profundus profundus and A. profundus tomilovi, inhabit Lake Baikal. According to her (Mazepova, 1978) "the latter differs from the nominative subspecies by the following traits: antennular segments not stout; caudal rami shorter; lateral seta relatively shorter, a seta present on the outer margin of distal Đ4 endopodite segment instead of a spine as in $A$. profundus profundus". Our morphometric analysis also shows some consistent differences between $A$. profundus tomilovi and A. profundus profundus (Table 3 ). It should be mentioned that these taxa also have a different armature of the first $\mathrm{P} 4$ exopodite segment. For instance, the P4 exopodite in A. profundus profundus is armed as follows: 1-0;1-1;3-4 (first number - spine, second - seta), it means that a seta which is present in A. profundus, yet absent in P. tomilovi (Table 1). Moreover, the two taxa occur in different habitats in Lake Baikal. A. profundus 


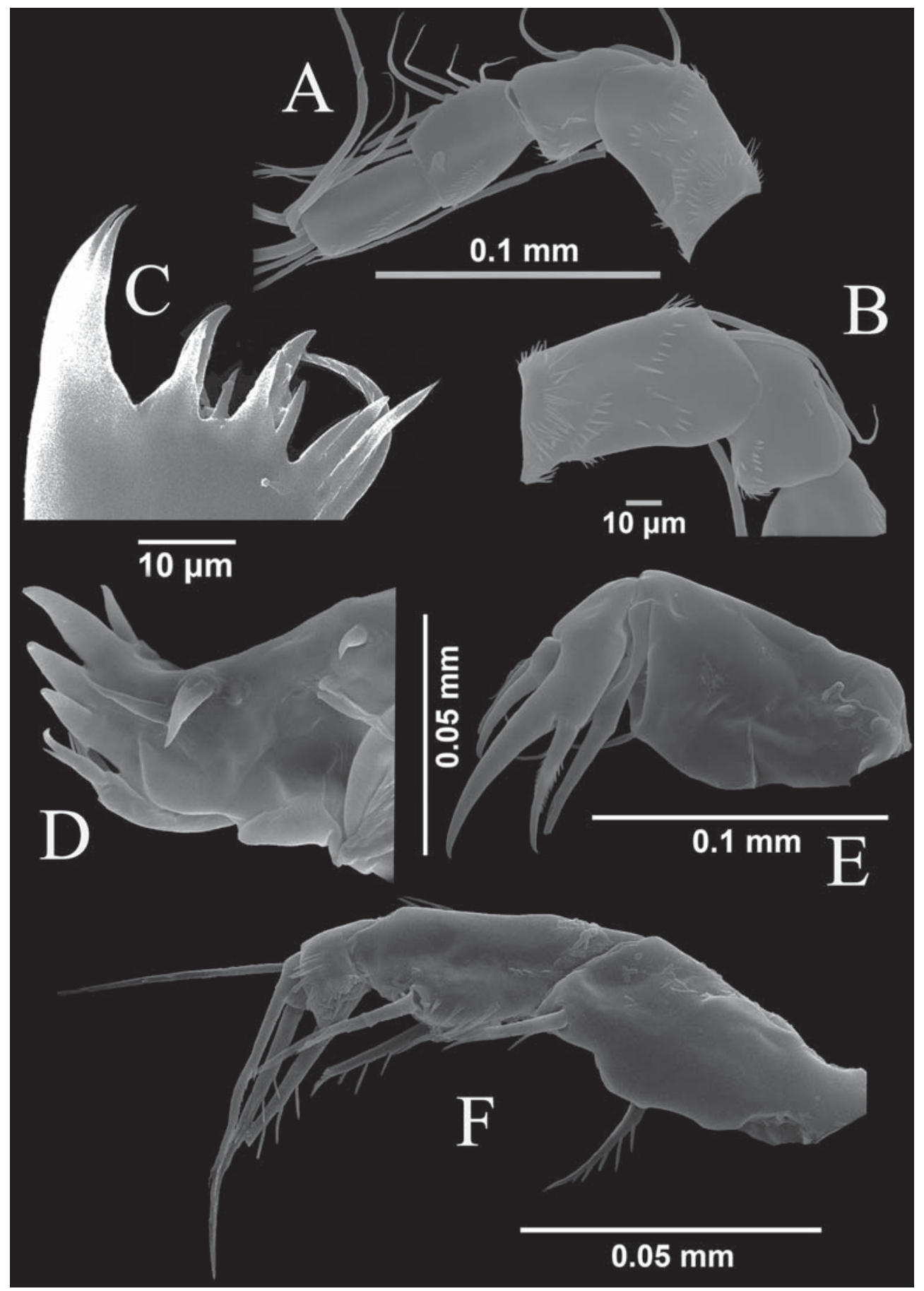

Fig. 2. Acanthocyclops tomilivi, female. A- antenna, caudal side; B - basipodite of antenna and first segment of antenna, caudal side; $\mathrm{C}$ - mandible; D - maxillula; $\mathrm{E}$ - maxilla; $\mathrm{F}$ - maxilliped.

Pис. 2. Acanthocyclops tomilivi, female. A - антенна, каудальная сторона; В - базиподит и первый членик антенны; C - мандибула; D - максиллула; E — максилла; F — максиллопед. 
Table 2. Main morphometric indices of Acantocyclops tomilovi from the littoral zone of Bolshye Koty Bay.

Таблица 2. Основные морфометрические показатели Acantocyclops tomilovi из литоральной зоны залива Большие Коты.

\begin{tabular}{lcc}
\hline Index & \multicolumn{2}{c}{ Female (n=15) } \\
\cline { 2 - 3 } & Average & Min-max \\
\hline $\begin{array}{l}\text { Body length, mm } \\
\text { Body length : cephalothorax width }\end{array}$ & 1193 & $1150-1225$ \\
$\begin{array}{l}\text { Furca length : width } \\
\text { Ti :Te } \\
\text { (ratio of inner and outer apical setae length) }\end{array}$ & 2.4 & $2-2.6$ \\
$\begin{array}{l}\text { Ti : L furca } \\
\text { (ratio of inner apical seta and furca length) }\end{array}$ & 1.4 & $1.31-1.46$ \\
$\begin{array}{l}\text { Ti : Tmi } \\
\text { (ratio of inner apical and inner median setae length) }\end{array}$ & 0.19 & $1.13-1.5$ \\
$\begin{array}{l}\text { Ti :Tme } \\
\text { (ratio of inner apical and outer median setae length) }\end{array}$ & 0.34 & $0.19-0.2$ \\
$\begin{array}{l}\text { Ti : Td } \\
\text { (ratio of inner apical and dorsal seta length) }\end{array}$ & 0.89 & $0.3-0.36$ \\
$\begin{array}{l}\text { Tmi : Tme } \\
\text { (ratio of inner median and outer median setae length) }\end{array}$ & 1.8 & $0.87-0.9$ \\
$\begin{array}{l}\text { 3EndP4 L:W } \\
\text { (ratio of endopodite length and width) }\end{array}$ & $1.74-1.84$ \\
$\begin{array}{l}\text { P4 outer spine } \\
\text { P4 L inner apical spine }\end{array}$ & $1.67-1.8$ \\
$\begin{array}{l}\text { Inner spine } \\
\text { P4 L inner apical spine }\end{array}$ & 63.6 & $53-75$ \\
Number of eggs in egg sac & 65 & $55-77$ \\
\hline
\end{tabular}

tomilovi is registered in the littoral $(5-20 \mathrm{~m})$ and sublittoral $(20-70 \mathrm{~m})$ zones, it prefers the bottom with plant detritus. At the same time, $A$. profundus profundus dwells in the sublittoral (20-70 m) and abyssal zones (collected at the depth slightly exceeding $500 \mathrm{~m}$ ) on silty substrates.

Due to these differences, the status of $A$. profundus profundus should be raised to a separate species. Also the former could not be regarded as a subspecies of $A$. profundus as both occur in the same water body, Lake Baikal.

V.R. Alekseev (in: Kozhova, Izmesteva, 1998) following data from previous publications (Mazepova, 1978; Alekseev, Arov, 1980; Flössner, 1984), mentioned 38 species of the cyclopoids in Lake Baikal. According to the last list of Mazepova (2001), there are 43 cyclopoid species and subspecies in Baikal fauna from eight genera: Macrocyclops Claus, 1893; Para- cyclops Claus, 1893; Eucyclops Claus, 1893; Orthocyclops Forbes, 1897; Cryptocyclops Sars, 1927; Acanthocyclops Kiefer, 1927; Mesocyclops Sars, 1914; Cyclops Müller, 1776. Russian authors usually followed the classification of Rylov (1948) and did not divide the genus Acanthocyclops into the genera Diacyclops Kiefer, 1927 and Acanthocyclops Kiefer, 1927. However, the morphological features of Đ5 (relatively short inner spine of the apical segment and its subapical location) indicate that this species belongs to the genus Acanthocyclops, together with Acanthocyclops similis Flössner, 1984; A. galbinus Mazepova, 1962; A. notabilis Mazepova, 1950; A. profundus profundus Mazepova, 1950; A. profundus tomiloivi Mazepova, 1978; A. rupestris rupestris Mazepova, 1950; A. rupestris signifer Mazepova, 1978 and A. vernalis (Fisher, 1853) (Monchenko, 1974; Dussart, Defaye, 2006). 


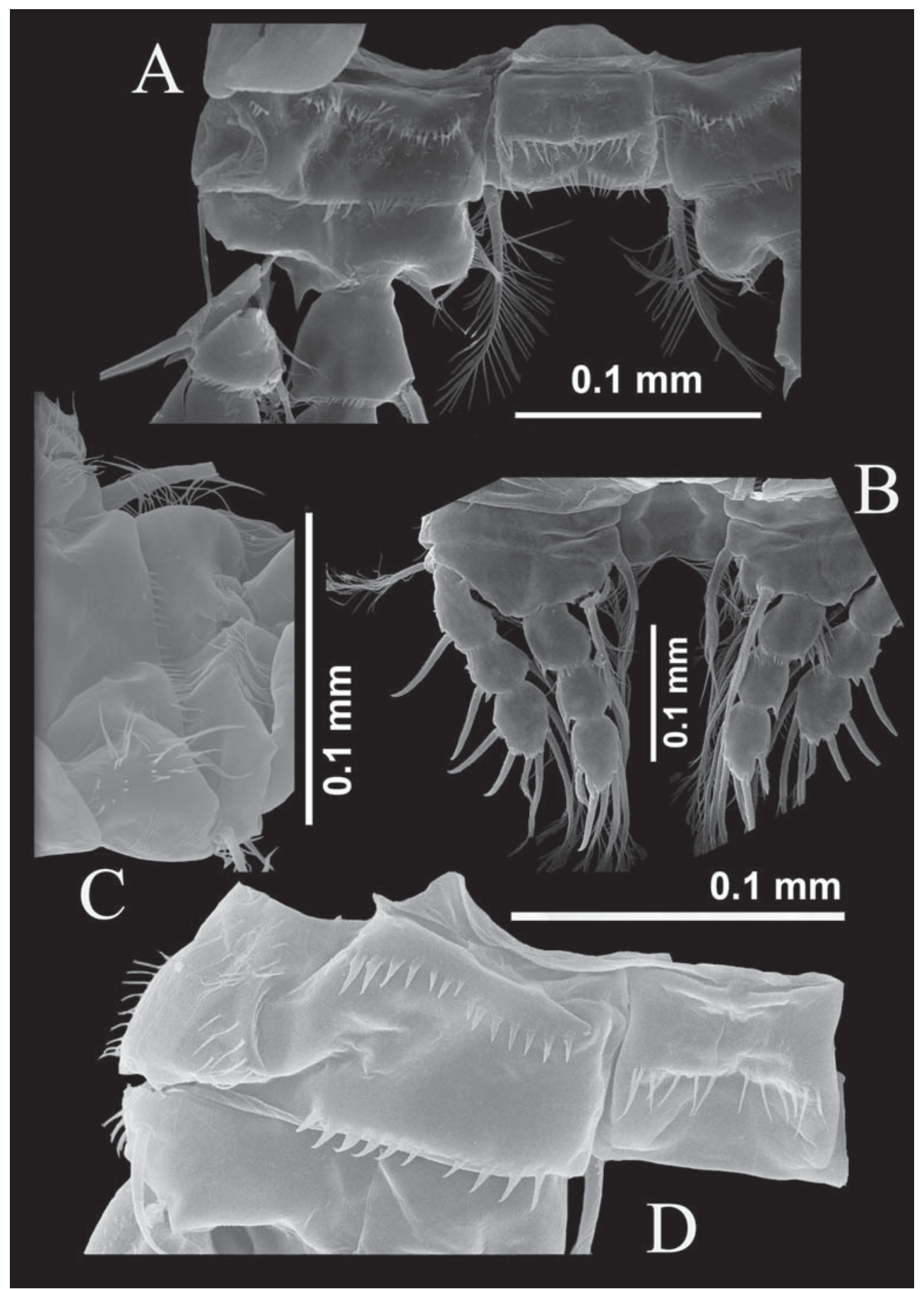

Fig. 3. Acanthocyclops tomilivi, female. A - coxa and coupler of $\mathrm{P} 4 ; \mathrm{B}-\mathrm{P} 1 ; \mathrm{C}-\operatorname{coxa}$ of $\mathrm{P} 3$, lateral; D coxa and coupler of $\mathrm{P} 3$.

Pис. 3. Acanthocyclops tomilivi, самка: А - коксоподит и соединительная пластинка P4; В - P1; C коксоподит Р3, вид с боку; D - коксоподит и соединительная пластинка Р3. 
Table 3. Morphometry of A. tomilovi and A. profundus profundus (A - original data; B — after Mazepova, 1978).

Таблица 3. Промеры A. tomilovi и A. profundus profundus (А - собственные данные, В - по Мазеповой, 1978).

\begin{tabular}{lcccc}
\hline Index & \multicolumn{2}{c}{ A } & \multicolumn{2}{c}{ B } \\
\hline & $\begin{array}{c}\text { A. profundus } \\
\text { tomilovi } \\
\text { Min-max }\end{array}$ & $\begin{array}{c}\text { A. profundus } \\
\text { profundus } \\
\text { Min-max }\end{array}$ & $\begin{array}{c}\text { A. profundus } \\
\text { tomilovi } \\
\text { Min-max }\end{array}$ & $\begin{array}{c}\text { A. profundus } \\
\text { profundus } \\
\text { Min-max }\end{array}$ \\
\hline Body length, $\mu \mathrm{m}$ & $1150-1225$ & $1250-1425$ & $740-1460$ & $1400-1500$ \\
Furcal rami;L/ W & $2-2.6$ & $2.6-3.3$ & $1.5-3.0$ & $>3$ \\
P4End3 L/ W & $1.67-1.8$ & $1.86-1.91$ & $1.0-1.8$ & 1.7 \\
\hline
\end{tabular}

Table 4. Subdivision of the genus Acanthocyclops Kiefer, 1927 into groups according to Einsle (1996). Таблица 4. Разделение видов рода Acanthocyclops Kiefer, 1927 на группы по Einsle (1996).

\begin{tabular}{|c|c|c|c|c|}
\hline Taxon & Group & $\begin{array}{c}\text { No. of } \\
\text { segments in } \\
\text { antennule }\end{array}$ & $\begin{array}{l}\text { No. of segments } \\
\text { in swimming legs } \\
(\mathrm{P} 1-\mathrm{P} 4)\end{array}$ & $\begin{array}{l}\text { Armature of distal } \\
\text { segment of } \\
\text { exopodite of P1-P4 }\end{array}$ \\
\hline A. galbinus & I & 11 & $22 / 32 / 33 / 33$ & 3.3.3.3. 5.4.4.4 \\
\hline A. similis & I & 11 & $33 / 33 / 33 / 33$ & 2.3.3.3 4.4.4.4. \\
\hline A. profundus & I & 11 & $33 / 33 / 33 / 33$ & 2.3.3.3. 4.4.4.4. \\
\hline A. tomilovi & I & 11 & $33 / 33 / 33 / 33$ & 2.3 .3 .3 .4 .4 .4 .4 \\
\hline A. notabilis & I & 11 & $33 / 33 / 33 / 33$ & 2.3.3.3. 4.4.4.4. \\
\hline $\begin{array}{l}\text { A. rubestris } \\
\text { rupestris }\end{array}$ & II & 12 & $33 / 33 / 33 / 33$ & 2.3.3.3. 4.4.4.4 \\
\hline $\begin{array}{l}\text { A. rubestris } \\
\text { signifer }\end{array}$ & II & 12 & $33 / 33 / 33 / 33$ & 2.3 .3 .3 .4 .4 .4 .4 \\
\hline A. vernalis & III & 17 & $33 / 33 / 33 / 33$ & 2.3 .3 .3 .3 .4 .4 .4 \\
\hline
\end{tabular}

Cyclopoids of the genus Acanthocyclops could be subdivided into three groups according to Einsle (1996), mainly based on the number of antennular segments. The first and second groups include endemic species that are abundant in Baikal and occur in the open littoral in the lake bays at the depths from 2-3 to $700 \mathrm{~m}$ on various types of substrate. The third group (with 17 antennular segments) includes a Holarctic species A. vernalis. Only few specimens of this species were observed in the coastal area and small lakes of the Baikal area.

Thus, Baikal endemics contributed much to the diversity in the genus Acanthocyclops, and deserve more study.

\section{Acknowledgements}

This work is supported by the Federal Project No. 0345-2016-0009 "Large-scale changes in ecology and biodiversity of coastal zone communities of Lake Baikal: interdisciplinary research, reasoning and prognosis" (supervised by Prof. O.A. Timoshkin). Analysis of the material was performed at the Joint-Use Center "Ultra-microanalysis" LIN SB RAS. Thanks to E.M. Timoshkina for the English translation of this paper and Dr. K. Van Damme for linguistic corrections.

\section{References}

Alekseev V.R., Arov I.V. 1980. [A new cyclopoid of the genus Diacyclops (Crustacea, Copepoda)] // Zool. Zhurn. Vol.65. No.7. P.1984-1087 [in Russian, with English summary].

Dussart B.H., Defaye D. 2006. World Directory of Crustacea Copepoda of Inland Waters II- Cyclopiformes. Leiden: Backhuys Publishers. 354 pp.

Dussart B.H., Defaye D. 2001. Introduction to the Copepoda. Guides to the identification of the microinverte- 
brates of the continental waters of the world. Vol.16. Leiden: Backhuys Publishers. 344 pp.

Flössner D. 1984. Two new species of the genera Acanthocyclops and Diacyclops (Crustacea, Copepoda) from Lake Baikal // Limnologica. Vol.15. No.1. P.149156.

Flössner D. 1972. Krebstiere, Crustacea (Kiemen- und Blattfüber, Branchiopoda, Fischläuse, Branchiura) // Die Tierwelt Deutschland. Bd.60. S.1-499.

Kozhova O.M., Izmesteva L.R. (eds.). 1998. Lake Baikal. Leiden: Backhuys Publishers. 447 pp.

Kozminski Z. 1936. Morfometrische und ökologische Untersuchungen an Cyclopiden der strenuus-Gruppe // Int. Revue ges. Hydrobiol. Hydrogr. Bd.33. S.161240 .
Mazepova G.F. 1950. [Knowledge on the fauna of Cyclopoida of Lake Baikal] // Dokl. Akad. Nauk SSSR. Vol.72. No.4. P.809-812 [in Russian].

Mazepova G.F. 1978. [Cyclopoids of Lake Baikal]. Novosibirsk: Nauka. 142 pp. [In Russian]

Mazepova G.F. 2001. [Cyclopoids (Cyclopoida)] // Timoshkin O.A. (ed.). Index of animal species inhabiting Lake Baikal and its catchment area. Lake Baikal. Vol.1. Book 1. Novosibirsk: Nauka. P.451-467 [in Russian].

Monchenko V.I. 1974. [Cyclopidae of Ukraine]. Kiev: Naukova Dumka. 452 p. [In Ukrainian]

Rylov V.M. 1948. [Cyclopoida of fresh waters] // Fauna SSSR. Crustacea. Vol.3. Issue 3. Moscow, Leningrad: AN SSSR Publ. 318 p. [in Russian]

Responsible editor A.A. Kotov 